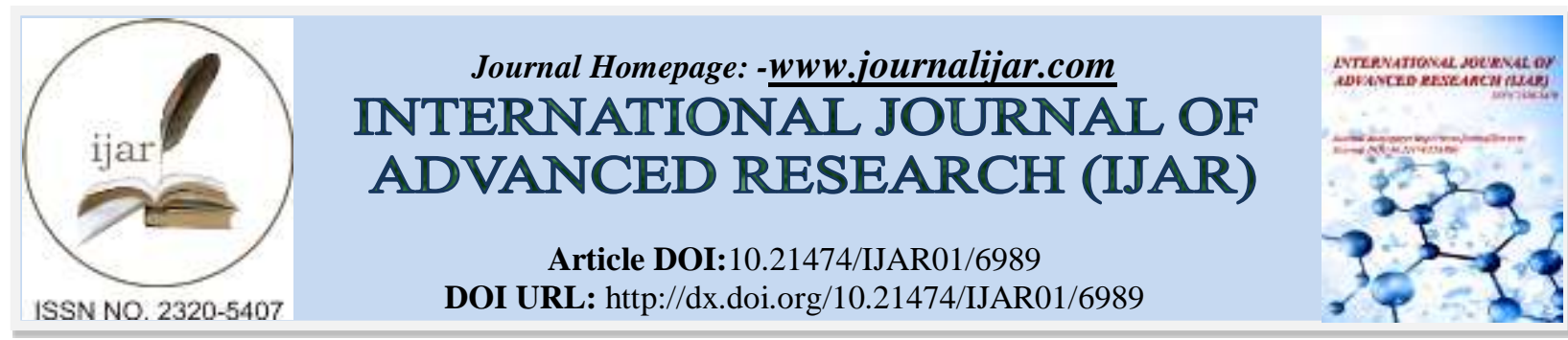

RESEARCH ARTICLE

\title{
ROLE AND PERFORMANCE OF THE WOMEN REPRESENTATIVES OF PRIS AND ULBs: A CASE STUDY OF BALASORE DISTRICT OF ODISHA.
}

\author{
Kanti Sethi. Research Scholar ${ }^{1}$ and Prof. Shayma Sundar Acharya ${ }^{2}$. \\ 1. Dept. of Social Science, F.M. University. \\ 2. Visiting Professor, Ravenshaw university.
}

\section{Manuscript Info}

Manuscript History

Received: 19 February 2018

Final Accepted: 21 March 2018

Published: April 2018

Keywords:-

Democracy, Grassroots, Leadership,

Participation Pri(Panchayati Raj

Institution), Ulb(Urban Local Body).

\begin{abstract}
Local self-government has always been considered as a means to good governance and $73^{\text {rd }}$ and $74^{\text {th }}$ Constitutional Amendments were made in the hope that they would lead to better governance and provide political space to the disadvantaged sections of the society like Scheduled Castes, Scheduled Tribes and specially women. This paper discusses about the comparison between the role performance of lady representatives of rural and urban local bodies during the period from 2012 to 2017.This paper is the result of a doctoral research carried out on the basis of stratified random sampling in the urban and rural areas of the district of Balasore. A higher percentage of Urban Local body members is found to attend all municipal meetings. A preponderant majority of the respondents of the Urban bodies vis-à-vis rural bodies is found to participate in all discussion. More number of them in the urban bodies claims to be competent in conflict resolution. However, most of the representatives of both the bodies admit to have depended on their husbands and family members.
\end{abstract}

Copy Right, IJAR, 2018,. All rights reserved.

\section{Introduction:-}

The success of democracy depends upon the decentralization of power. Through the system of local self government power can be properly decentralized and people can obtain their democratic rights and live in an environment of equality and liberty. Since the members of the local self government are local people, they can realize and understand the gravity of the local problems more properly than the administrators of the state or central government. Panchayati Raj and municipal system in India are the most important landmarks in the history of administrative reforms which emerged out of $73^{\text {rd }}$ and $74^{\text {th }}$ Amendment Acts of Indian Constitution in 1992 to institutionalize peoples' participation at the grassroots level planning. These Amendment Acts opened up the windows of opportunities for women to emerge as leaders and play an effective role in the local bodies. One of the chief objectives of these amendment was to assign an active role to the women in decision making process at grassroots level and thereby to generate leadership qualities among them. Providing one third reservation (and subsequently fifty percent in 2011)of seats for the women along with the reservation of seats for S.C. \& S.T. women has been a major step in the direction of democratization and political empowerment of women.

\section{Objectives of the Study:-}

1. To inquire into the role of women representatives during the year 2012-2017. 
2. To examine their participatory behaviour in decision making process during the study period.

3. To compare the performance of women representatives from both rural and urban bodies on the basis of the study.

\section{Methodology:-}

The major concern of the present work is to compare the role and performance of the women leaders' of PRIs and ULBs of Balasore district of Odisha. For this purpose, 141 women leaders from PRIs from 2012 to 2017 have been selected as sample of study. All 48 women representatives from Urban local bodies of Balasore district during the period have been taken up for study. In other words, a comparative study between rural and urban women leaders of Balasore district is undertaken. Positivist method and quantitative techniques have been adopted to carry on the research work of which the present article is the product. A questionnaire with 51 number of questions was used for the purpose.

Role and performance of the functionaries of the urban and rural local bodies can be better asserted against the scenario of the background from which they are drawn. Hence, the tabular presentation of the various offices occupied by the functionaries and their social background has been made. The educational background of the women representatives and their husbands has been given to assess their role performance.

Table no.1:-Break up of Sample women leaders of PRIs.

\begin{tabular}{|l|l|l|l|l|l|}
\hline S1. No. & Blocks & ZP & PS & Sarpanch and WM & Total \\
\hline 1. & Jaleswar & 2 & 3 & 52 & 57 \\
\hline 2. & Balasore (Sadar) & 2 & 2 & 42 & 46 \\
\hline 3. & Simulia & 1 & 3 & 34 & 38 \\
\hline & Total & 5 & 8 & 128 & 141 \\
\hline
\end{tabular}

The above table shows the offices like Sarpanch and WM(Ward Member) occupied at different levels like ZP(Zilla Parishad) and PS(Panchayat Samiti) in the sample blocks of Balasore.

Table no.2:-Break up of Sample women leaders of Urban local bodies.

\begin{tabular}{|l|l|l|l|l|l|}
\hline Sl. No. & Municipality & Chairman & Vice Chairman & Councilors & Total \\
\hline 1. & Jaleswar (NAC) & - & 1 & 9 & 10 \\
\hline 2. & Balasore (Municipality) & - & 1 & 17 & 18 \\
\hline 3. & Soro (NAC) & 1 & - & 9 & 10 \\
\hline 4. & Nilgiri (NAC) & - & 1 & 9 & 10 \\
\hline & Total & 1 & 3 & 44 & 48 \\
\hline
\end{tabular}

The above table shows the offices of Chairman, Vice-Chairman, Councilors occupied in all the Urban bodies of Balasore district.

Table no.3:-Caste composition of the representatives

\begin{tabular}{|c|l|l|l|l|c|c|}
\hline Respondents & ST & SC & OBC & Gen & Others(Muslims) & Total \\
\hline PRI & $23(16.31 \%)$ & $\begin{array}{c}55 \\
(39 \%)\end{array}$ & $\begin{array}{c}19 \\
(13.47 \%)\end{array}$ & $\begin{array}{c}44 \\
(31.20 \%)\end{array}$ & - & $(100 \%)$ \\
\hline ULB & $10(20.83 \%)$ & $7(14.58 \%)$ & $13(27.08 \%)$ & $14(29.16 \%)$ & 4 & 48 \\
$(100 \%)$ \\
\hline
\end{tabular}

The above table shows the caste/ethnicity composition of the sample members of rural bodies and all members of urban bodies.

Table no. 4:-Educational background of Women Representatives

\begin{tabular}{|c|c|c|c|c|c|c|c|}
\hline Respondents & Illiterate & Primary & Secondary & $\begin{array}{c}\text { Higher } \\
\text { Secondary }\end{array}$ & Graduation & $\begin{array}{c}\text { Post } \\
\text { graduation }\end{array}$ & Total \\
\hline PRI & 7 & 24 & 26 & 69 & 15 & - & 141 \\
& $(4.96 \%)$ & $(17.02 \%)$ & $(18.43 \%)$ & $(48.93 \%)$ & $(10.63 \%)$ & 6 & $(100 \%)$ \\
\hline ULB & - & 6 & 7 & 26 & 6 & 3 & 48 \\
& & $(12.5 \%)$ & $(14.58 \%)$ & $(54.16 \%)$ & $(12.5 \%)$ & $(6.5 \%)$ & $(100 \%)$ \\
\hline
\end{tabular}


Table no.5:- Educational Level of Leaders' Husbands

\begin{tabular}{|c|c|c|c|c|c|c|c|c|}
\hline Respondents & Illiterate & Pry & Secondary & $\begin{array}{c}\text { Higher } \\
\text { Secondary }\end{array}$ & Graduation & P.G. & $\begin{array}{c}\text { Prof. } \\
\text { Edn }\end{array}$ & Total \\
\hline PRI & 3 & 35 & 41 & 25 & 29 & 3 & 5 & 141 \\
& $(2.12 \%)$ & $(24.82 \%)$ & $(29.07 \%)$ & $(17.73 \%)$ & $(20.56 \%)$ & $(3.54 \%)$ & $(3.54 \%)$ & $(100 \%)$ \\
\hline ULB & - & 4 & 6 & 19 & 13 & 3 & 6 & 48 \\
& & $(8.33 \%)$ & $(12.5 \%)$ & $(39.58 \%)$ & $(27.08 \%)$ & $(6.25 \%)$ & $(12.5 \%)$ & $(100 \%)$ \\
\hline
\end{tabular}

A comparative study of the educational qualification of the respondents and their husbands shows that in graduation, post-graduation and professional education category the husbands excel their better halves. In the graduation category the number of graduation is found the double among the husbands both in rural and urban bodies.

Role is a normative concept. Certain 'do's' and 'don'ts' are associated with the concept. The panchayat and municipal representatives are expected to take part in the meetings, discuss the confidential issues and attempt resolution of conflict. This is expected of them as popular representatives at the grassroots level.

Role-performance of the sample leaders has been assessed in terms of (i) the women leaders' participation in decision-making, (ii) extent of success in solving the problems of the people, (iii) independence of working without any outside interference, and (iv) experience regarding actual exercise of powers.

Table no.6:- Attendance on PRI/ Municipal meetings

\begin{tabular}{|l|l|l|l|l|l|}
\hline Respondents & None & Few & Most & All & Total \\
\hline PRIs & - & 2 & 51 & 88 & 141 \\
& & $(1.41 \%)$ & $(36.17 \%)$ & $(62.41 \%)$ & $(100 \%)$ \\
\hline ULBs & - & 3 & 6 & 39 & 48 \\
& & $(6.25 \%)$ & $(12.5 \%)$ & $(81.25 \%)$ & $(100 \%)$ \\
\hline
\end{tabular}

It is evident from Table no. 6 that $62.41 \%$ of the PRI and $81.25 \%$ ULB women leaders attended all local body meetings whereas $36.17 \%$ PRI and $12.5 \%$ ULB respondents attended most of the meetings. The high percentage of ULB members attending all meetings vis-à-vis their rural counterparts is quite likely since they are drawn from the urban background. The women leaders attending meetings held once in a month along with doing their household work is a positive sign of their performance.

Table-7:-Women leaders' participation in discussion

\begin{tabular}{|l|l|l|l|l|l|}
\hline Respondents & None & Few & Most & All & Total \\
\hline PRIs & 13 & 14 & 58 & 56 & 141 \\
& $(9.21 \%)$ & $(9.92 \%)$ & $(41.13 \%)$ & $(39.71)$ & $(100 \%)$ \\
\hline ULBs & 1 & 2 & 5 & 40 & 48 \\
& $(2.08 \%)$ & $(4.16 \%)$ & $(10.41 \%)$ & $(83.33 \%)$ & $(100 \%)$ \\
\hline
\end{tabular}

It is found from table-7 that $83.33 \%$ of the representatives of the ULBs vis-à-vis only $39.71 \%$ of PRI representatives participating in 'all discussion' is indicative of the political awareness of the representatives from urban background. Of PRIs $41.13 \%$ respondents participate in most of the meetings, $9.21 \%$ representatives do not take part in any discussion and they are found to belong to ST category and due to lack of education and political experience they shy away from discussion.

Table-8:-Role in solving peoples' problems

\begin{tabular}{|c|c|c|c|c|c|}
\hline Respondents & $\begin{array}{c}\text { Fully } \\
\text { successful }\end{array}$ & Partly successful & Not at all & No reply & Total \\
\hline PRIs & $\begin{array}{c}56 \\
(39.71 \%)\end{array}$ & $\begin{array}{c}69 \\
(48.93 \%)\end{array}$ & $\begin{array}{c}16 \\
(11.34 \%)\end{array}$ & $\begin{array}{c}2 \\
(1.41 \%)\end{array}$ & $\begin{array}{c}141 \\
(100 \%)\end{array}$ \\
\hline ULBs & 19 & 22 & 4 & 3 & 48 \\
& $(39.58 \%)$ & $(45.83 \%)$ & $(8.33 \%)$ & $(6.25 \%)$ & $(100 \%)$ \\
\hline
\end{tabular}

It is found from table no. 8 that $39.71 \%$ of the PRI leaders and $39.58 \%$ leaders of ULBs claim to have been able to solve the problems which were raised in their respective meetings. Data further show that $48.93 \%$ PRI and $45.83 \%$ respondents of ULBs are partly successful in this respect. It is found from data that there is no marked difference in solving capacity of both the areas. It is evident that nearly 11 percent respondents in PRIs and 9 percent respondents 
of ULBs reported that they have not solved any problem. This might be due to lack of concern about their local problems and lack of confidence in handling the task.

Table-9:-Role in Conflict Resolution

\begin{tabular}{|c|c|c|c|c|c|}
\hline Respondents & Always & Some times & Never & No reply & Total \\
\hline PRIs & 27 & 74 & 33 & 7 & 141 \\
& $(19.14 \%)$ & $(52.48 \%)$ & $(23.40 \%)$ & $(4.96 \%)$ & $(100 \%)$ \\
\hline ULBs & 17 & 25 & 5 & 1 & 48 \\
& $(35.41 \%)$ & $(52.08 \%)$ & $(10.41 \%)$ & $(2.08 \%)$ & $(100 \%)$ \\
\hline
\end{tabular}

Data from table no. 9 shows that about 19 percent of the sample PRI leaders and $35.41 \%$ of ULB leaders are always needed by the people for resolving any local conflict. It is evident from the table that $23.40 \%$ from PRIs and $10.41 \%$ ULB sample leaders are never needed by the local people for conflict resolution.

Table no.10:-Dependence of Women Representatives on others

\begin{tabular}{|c|c|c|c|c|c|c|}
\hline Respondents & Husband & $\begin{array}{c}\text { Family } \\
\text { members }\end{array}$ & Relatives & $\begin{array}{c}\text { Pol. } \\
\text { Leaders }\end{array}$ & $\begin{array}{c}\text { Local } \\
\text { people }\end{array}$ & $\begin{array}{c}\text { Total } \\
\text { PRIs }\end{array}$ \\
\hline ULBs & 106 & 7 & 2 & 4 & 2 & 141 \\
$(87.70 \%)$ & $(5.78 \%)$ & $(1.65 \%)$ & $(3.30 \%)$ & $(1.65 \%)$ & $(100 \%)$ \\
\hline & 34 & 6 & - & 3 & 1 & 48 \\
$(17.27 \%)$ & $(13.63 \%)$ & & $(6.81 \%)$ & $(2.27 \%)$ & $(100 \%)$ \\
\hline
\end{tabular}

From table no.10 it is clear that a preponderant majority of PRI (87.60\%) and ULB(77.27\%) representatives depend on their husbands. From the data it is clear that 5.78\% PRI leaders and $13.63 \%$ ULB leaders depend on their family members. Here in both the areas it is found that the respondents are not working independently while exercising their powers. This makes clear the significance of 'Sarpanch Pati' phenomenon at the rural grassroots level. Even dependence of the representatives of ULBs on their husbands view is manifest.

Table-11:-Opinion on Actual exercise of power by their husbands or male family members

\begin{tabular}{|c|c|c|c|c|c|}
\hline Respondents & Fully true & Partly true & Not at all true & No reply & Total \\
\hline \multirow{2}{*}{ PRIs } & 72 & 49 & 17 & 3 & 141 \\
& $(51.06 \%)$ & $(34.75 \%)$ & $(12.05 \%)$ & $(2.12 \%)$ & $(100 \%)$ \\
\hline \multirow{2}{*}{ ULBs } & 27 & 13 & 7 & 1 & 48 \\
& $(56.25 \%)$ & $(27.08 \%)$ & $(14.58 \%)$ & $(1.72 \%)$ & $(100 \%)$ \\
\hline
\end{tabular}

Data from table no. 11 shows that $51.06 \%$ of PRIs and $56.25 \%$ ULBs respondents point out power being exercised by their husbands is 'fully true'. $34.75 \%$ PRIs and $27.08 \%$ respondents of ULBs considered it as partly true. Those sample leaders who expressed their view about the dominance of male members were further asked the reasons for such dominance. For this, they mentioned reasons like their lack of political experience, illiteracy, inferiority complex of being a woman, lack of exposure, dominant nature of men in the society etc.

The comparison of the educational qualification of the representatives and their husbands shows that the later have higher representation in higher education both in general and professional categories. This constitutes an important explanation of women representatives in both types of bodies being dominated by their husbands and the representative wives have no hesitation in revealing this fact.

\section{Conclusion:-}

This study is a comparison between the role and performance of the representatives of the Panchayati Raj Institutions(PRIs) and Urban Local Bodies(ULBs). The lady representatives of the ULBs are better equipped educationally against their rural counterparts. Corresponding to the greater cognitive orientation(Acharya,2008) of the respondents of the urban bodies, they are found to be more active than the rural counterparts. It is natural that given better education, income background and greater political orientation they display more interest in the political participation. Since it is observed that the lady representatives both in the urban and rural bodies lag behind their husbands in educational qualification which may be a cause of their being dependent on the husbands/family members. It is very much essential to raise the educational standard of women. Moreover, the new entrants to PRIs 
and municipal bodies must be given orientation to handle their office requirements and perform their roles properly. Through micro finance their economic standard can be raised which will make the rural representatives catch up with the urban counterparts and allow urban representatives to fare representatives still better so that women empowerment at the grassroots level will be a reality.

\section{References:-}

1. Acharya, S.S.(2008) ), “The New Panchayati Raj System: Retrospect and Prospect" in "Working of the New Panchayati Raj System in India, Dreams and Realities", P. Das(ed.), Zenith Publications, Bhadrak, Orissa

2. Patel, Amrit (2010): “Empowerment of Rural Women", Kurukshetra, June,2010

3. Rajput, Pan(2001): Womens' Political Participation in India: An Agenda for Empowerment" in Empowering the Indian Women(ed), Dr. Pramila Kapoor, New Delhi: Publication Division, Ministry of Information \& Broadcasting, Govt of India,p.240 